\title{
Embriogênese somática a partir de embriões imaturos em genótipos de milho
}

\author{
Somatic embryogenesis from immature embryos in maize genotypes
}

\author{
Eloise Helena Fernandes ${ }^{\mathrm{I}}$ Alberto José Prioli ${ }^{\mathrm{I}}$ Carlos Alberto Scapim ${ }^{\mathrm{I}}$ Ivan Schuster ${ }^{\mathrm{II}}$ \\ Elisa Serra Negra Vieira ${ }^{I I}$ Antônio Teixeira do Amaral Júnior ${ }^{\mathrm{III}}$ Lia Mara Moterle
}

\section{- NOTA -}

\section{RESUMO}

A primeira etapa de um programa de transformação genética de plantas é o estabelecimento de um protocolo de regeneração de plantas, a partir de cultura de tecidos. A regeneração de plantas pode ser conseguida por meio de organogênese ou embriogênese. A embriogênese somática é dependente do genótipo das plantas utilizadas e a identificação de genótipos mais responsivos a este método de regeneração resulta em maior eficiência da técnica. O trabalho teve como objetivo identificar genótipos de milho com maior capacidade de produção de embriões somáticos e regeneração de plantas. Foram investigados 11 genótipos (linhagens $e$ híbridos). As culturas foram obtidas a partir de embriões imaturos, inoculados em meio N6, suplementado com $690 \mathrm{mg}$ $L^{-1}$ de prolina e $10 \mu M$ de 2,4-D, com subcultivos quinzenais. Nos genótipos LD82025, CD308 e CML314, foram observados calos do tipo II, friáveis e embriogênicos. Esses genótipos foram submetidos ao processo de regeneração, destacando-se a linhagem LD82025. Os genótipos CD307, CD304, OC-705, 105-B e o GU04328 não apresentaram indução de calos embriogênicos. Os resultados indicam que a linhagem LD82025 é a mais promissora para utilização em um programa de transformação genética de plantas.

Palavras-chave: Zea mays, cultura de tecidos, regeneração.

\section{ABSTRACT}

The establishment of a protocol for regenerating plants by tissue culture is the first step in breeding programs which have the objective of using genetic transformation on plants. The plant regeneration can be achieved either by organogenesis or embryogenesis. In the second case, the somatic embryogenesis depends on the identification of responsive genotypes which enhance the efficiency of the program. The aim of the present study was to identify maize genotypes with high capacity to produce somatic embryos and consequently regenerate maize plants. Eleven genotypes (inbreds and hybrids) were investigated in the present experiment. Under two-week periods, the cultures were obtained from immature embryos which were inoculated into growing medium N6 with $690 \mathrm{mg} \mathrm{L}^{-1}$ of proline and $10 \mu \mathrm{M}$ of 2,4-D. Callis of type II, friable and embryogenic, were observed in the LD82025, CD308, and CML314 genotypes. After, they were submitted to the regeneration process and the best performance was achieved by the LD82025. No embryogenic callus was developed from CD307, CD304, OC-705, 105-B, and GU04328. In the present case, the inbred LD82025 is the most promising maize genotype for participating in a breeding program that will use the genetic transformation of maize plants.

Key words: Zea mays, tissue culture, regeneration.

No Brasil, o milho é cultivado em todo o território. Ao lado da soja, é uma das culturas mais importantes da agricultura brasileira e uma das responsáveis pelo rápido crescimento na produção brasileira de grãos. A produção da safra brasileira em 2004/2005 foi em torno de 35,0 milhões de toneladas, com produtividade de $2.867 \mathrm{~kg} \mathrm{ha}^{-1} \mathrm{em} 12,2$ milhões de hectares de área plantada (CONAB, 2005). A produção nacional de milho não é suficiente para atender as demandas do mercado interno, gerando problemas de abastecimento para a indústria nacional. A solução para esse problema seria a expansão da área plantada e o aumento da produtividade das áreas atualmente cultivadas.

'Departamento de Agronomia, Universidade Estadual de Maringá (UEM), 87020-900, Maringá, PR, Brasil. E-mail: cascapim@uem.br.

*Autor para correspondência.

"Cooperativa Central de Pesquisa Agrícola (COODETEC), Cascavel, PR, Brasil.

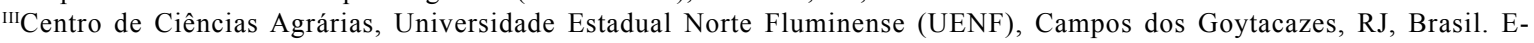
mail:amaraljr@uenf.br. 
A engenharia genética, por meio do processo de transformação de plantas, pode possibilitar a obtenção de genótipos mais produtivos e adaptados aos diversos sistemas de cultivo. De acordo com CARNEIRO et al. (2000), o milho transgênico traz incremento médio de $8 \%$ na produtividade e esse aumento está relacionado a eventos que contribuem com o aumento da resistência a insetos, a herbicidas e às condições adversas. Diferentes metodologias de transformação genética de plantas foram estabelecidas recentemente, com o desenvolvimento de técnicas de cultura de tecidos e da engenharia genética (BRASILEIRO \& CARNEIRO, 1998). Entre elas, podese citar: transformação indireta via Agrobacterium tumefaciens, eletroporação, biobalística, microinjeção, entre outras. Para que um programa de transformação de plantas seja eficiente, é necessário que haja uma forma adequada de introdução do gene na espécie e posterior regeneração das células transformadas até a obtenção de uma planta completa. O desenvolvimento da metodologia de propagação e cultura de tecidos via embriogênese somática ou organogênese é estratégia adequada para o estabelecimento de um protocolo eficiente de transformação genética (MILACH et al., 1991).

Assim, o objetivo deste trabalho foi identificar linhagens ou híbridos elite de milho que apresentem maior capacidade de produção de embriões somáticos e maior capacidade de regeneração de plantas a partir da embriogênese somática.

Foram utilizados 11 genótipos de milho (linhagens/híbridos) dos programas de melhoramento da Universidade Estadual de Maringá (UEM) e da Cooperativa Central de Pesquisa Agrícola (COODETEC), Paraná (PR). Os genótipos testados foram: um híbrido simples (CD307), um híbrido duplo (CD308), dois híbridos triplos (CD304 e CD306) e sete linhagens elite (GU04328-Maringá, OC-705, 105-B, LD82025, CML314, 202-C e XE23041-B). As sementes dos híbridos e das linhagens foram cultivadas em casa de vegetação $\left(28^{\circ} \mathrm{C} \pm 5^{\circ} \mathrm{C}\right.$ com fotoperíodo natural de 14 horas luz). Foram usados três vasos para cada genótipo, com duas plantas por vaso, com o objetivo de obter os embriões imaturos necessários para a instalação do ensaio. Todas as plantas foram autopolinizadas e entre 14 e 18 dias após a autopolinização (dependendo do ciclo do material) as espigas foram colhidas para a retirada dos embriões imaturos. Nesta fase, os grãos apresentavam-se no estado leitoso.

O experimento foi inteiramente ao acaso, com número diferente de repetições. Cada repetição foi constituída por uma placa com 10 embriões. O número de repetições variou de três a oito, em função do número de embriões padrão resgatados com menos de $2 \mathrm{~mm}$ de comprimento. As espigas utilizadas para a dissecação dos embriões imaturos foram inicialmente desinfetadas sem palha em uma solução 1:1 de hipoclorito de sódio (2,5\%) e água com duas gotas por litro de Tween 20 , em seguida, foram lavadas duas vezes em água destilada autoclavada.

Para a retirada dos embriões do interior dos grãos, realizou-se um corte longitudinal no topo dos grãos, sendo então retirados com o auxílio de agulhas histológicas esterilizadas e incubados em meio N6 (CHU et al., 1975) suplementado com L-prolina $(690 \mathrm{mg}$ $\left.\mathrm{L}^{-1}\right), 2$, $4-\mathrm{D}(10 \mu \mathrm{M})$, sacarose $\left(20 \mathrm{~g} \mathrm{~L}^{-1}\right)$ e Phytagel $\left(3 \mathrm{~g} \mathrm{~L}^{-1}\right)$. As culturas foram mantidas em salas de crescimento $\left(25^{\circ} \mathrm{C} \pm 1^{\circ} \mathrm{C}\right)$ no escuro, em todos os estágios, e foram subcultivadas a cada 15 dias sempre no mesmo meio.

A regeneração de plantas foi realizada 120 dias após o início da cultura pela transferência de 12 calos por genótipo para placas contendo meio N6 (na ausência de L-prolina e de 2,4-D) na presença de luz, com fotoperíodo de 16 horas luz e intensidade luminosa de $7 \mu \mathrm{Em}^{-2} \mathrm{~s}^{-1}$. Nesta etapa foram selecionados apenas os genótipos que apresentaram calos embriogênicos. A distinção entre calos embriogênicos e nãoembriogênicos foi feita visualmente, considerando os calos friáveis como embriogênicos. Quando esses calos começaram a emitir pontos verdes, foram cuidadosamente repicados e transferidos para caixas magenta contendo meio N6 à metade da concentração dos sais (1/2 N6). Quando as plântulas começaram a emitir raízes, foram trasferidas para bandejas com substrato orgânico e vermiculita e acondicionadas em casa de vegetação. As condições de cultivo foram de $28^{\circ} \mathrm{C} \pm 5^{\circ} \mathrm{C}$ e fotoperíodo natural, com 14 horas luz.

A análise dos dados foi feita por meio da estatística não-paramétrica aplicando-se o teste de Kruskal-Wallis, a $10 \%$ de probabilidade de erro, e as comparações múltiplas envolvendo todos os pares de genótipos.

Nos genótipos LD82025, CML314 e CD308, foi registrada a formação de pró-embriões sobre a superfície dos calos duas semanas após a inoculação. Os genótipos CD307, CD304, OC-705, 105-B e GU04328 geraram calo de aparência compacta e nãoembriogênicos. Calos com consistência aquosa foram observados nos genótipos CD306, 202-C e XE23041B. Os calos friáveis e embriogênicos foram produzidos pelos genótipos CD308, CML314 e LD82025. Estes mantiveram a capacidade de proliferação até o oitavo subcultivo. Os calos dos genótipos CD304 e 105-B não proliferaram no segundo subcultivo, enquanto que os calos da linhagem GU04328 proliferaram apenas até o segundo subcultivo. Da mesma forma, os genótipos 
CD307 e OC-705 produziram calos que suportaram somente até o terceiro subcultivo. O genótipo LD82025 foi o que apresentou o maior número de calos e também o maior número de plantas formadas (Tabela 1). Por meio dos resultados obtidos, é possível afirmar a influência do genótipo na regeneração de plantas de milho a partir da embriogênese somática.

Os genótipos CD304, 105-B, CD307 e OC705 se mostraram promissores nos primeiros subcultivos, mas sofreram redução na capacidade de indução de calos embriogênicos nos subcultivos seguintes. SMITH \& STREET (1974) afirmam que esse comportamento é comum e que, após um período prolongado de cultivo, o potencial embriogênico do calo declina e esse fenômeno pode variar de acordo com o genótipo, visto que alguns materiais suportam quantidades maiores ou menores de subcultivos. Essa correlaçao entre genótipo e resposta embriogênica em cultura de calos iniciadas a partir de embriões imaturos tem sido bem documentada por vários autores (GREEN \& PHILLIPS, 1975; TOMES \& SMITH, 1985). De acordo com OZGEM et al. (1996) e MACHII et al. (1998), o genótipo da planta doadora do embrião parece ser fundamental para o sucesso na obtenção de calos embriogênicos.

$\mathrm{Na}$ tabela 1, verifica-se que para os três genótipos o número de pontos verdes foi mais alto do que o número de plântulas transferidas tanto para caixa magenta quanto para vermiculita. Esse fato, provavelmente, pode ter ocorrido devido ao processo de aclimatização. Segundo SANTOS-SEREJO \& AGUIAR-PERECIN (2000), a aclimatização é etapa de grande influência no processo de regeneração de plantas, sendo que o grau de umidade, temperatura, época do ano e intensidade de luz são pontos que ainda devem ser otimizados para obtenção de maior rendimento de regenerantes. Poucos genótipos de milho são capazes de formar calos tipo II (embriogênico), o que sugere a ocorrência de controle genético na determinação do tipo de resposta ao cultivo in vitro (TOMES \& SMITH 1985). Entretanto, na literatura existem poucos relatos sobre os genes envolvidos na embriogênese somática e na regeneração de plantas de milho. Alguns autores demonstram que períodos de estresse durante o cultivo in vitro podem promover aumento nas taxas de indução, maturação e germinação de embriões somáticos (LEE et al., 2001; DRONNE et al.,1997).

Cada um dos genótipos avaliados deve necessitar de uma condição de cultivo diferente para indução de calos e regeneração de plantas. Isso significa que maiores investimentos para otimização das condições de cultivo para cada genótipo seriam de fundamental importância. A obtenção de um número

Tabela 1 - Médias e desvios-padrão do número de calos por placa, em cada subcultivo, produzidos a partir de 10 embriões imaturos por placa de 11 genótipos de milho e o desempenho dos genótipos LD82025, CD308 e CML314 quanto à regeneração de plantas.

\begin{tabular}{|c|c|c|c|c|c|c|c|c|}
\hline \multirow{2}{*}{ Genótipos tipo de calo } & \multicolumn{8}{|c|}{ 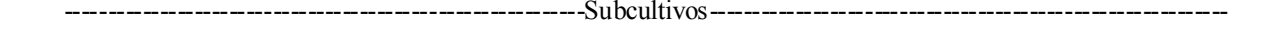 } \\
\hline & $1^{\mathrm{o}}$ & $2^{\circ}$ & $3^{\circ}$ & $4^{\circ}$ & $5^{\circ}$ & $6^{\circ}$ & $7^{\circ}$ & $8^{\circ}$ \\
\hline \multirow{4}{*}{$\begin{array}{l}\text { CD306 Aquoso } \\
\text { of CD307 Compacto } \\
\text { of } \\
\text { CD308 Friável* } \\
\text { CD304 Compacto }\end{array}$} & $7,0 \pm 2,64 \mathrm{bc}$ & $7,3 \pm 6,65 a b c$ & $18,0 \pm 18,52 \mathrm{abc}$ & $12 \pm 15,13 a b c$ & $11,3 \pm 12,66 \mathrm{~b}$ & $8,3 \pm 15,03 \mathrm{~b}$ & $5,3 \pm 9,23 \mathrm{c}$ & $5,3 \pm 6,65 \mathrm{c}$ \\
\hline & $6,1 \pm 2,23 \mathrm{c}$ & $4,5 \pm 4 a b c$ & $1,0 \pm 1,85 \mathrm{bc}$ & $0 \mathrm{c}$ & $0 \mathrm{c}$ & $0 \mathrm{~b}$ & $0 \mathrm{~d}$ & $0 \mathrm{c}$ \\
\hline & $15,1 \pm 4,64 \mathrm{ab}$ & $27,2 \pm 5,92 \mathrm{a}$ & $33,8 \pm 29,43 \mathrm{ab}$ & $33 \pm 30,43 \mathrm{ab}$ & $8,7 \pm 10,70 \mathrm{~b}$ & $7,3 \pm 8,38 \mathrm{~b}$ & $6,1 \pm 8,14 \mathrm{c}$ & $12,6 \pm 20,37 \mathrm{c}$ \\
\hline & $5,0 \pm 1,00 \mathrm{c}$ & $0 \mathrm{c}$ & $0 \mathrm{c}$ & $0 \mathrm{c}$ & $0 \mathrm{c}$ & $0 \mathrm{~b}$ & $0 \mathrm{~d}$ & $0 \mathrm{c}$ \\
\hline \multirow{8}{*}{ 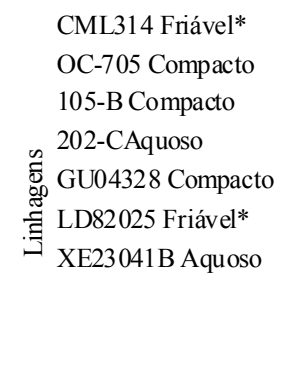 } & $10,1 \pm 2,47 \mathrm{abc}$ & $15,7 \pm 5,28 \mathrm{abc}$ & $27,2 \pm 22,44 \mathrm{ab}$ & $13,5 \pm 12,37 \mathrm{abc}$ & c $15,8 \pm 14,78 \mathrm{~b}$ & $24,3 \pm 25,44 \mathrm{a}$ & $20,8 \pm 25,02 b$ & $30,3 \pm 4,03 \mathrm{~b}$ \\
\hline & $11,2 \pm 2,60 \mathrm{abc}$ & $3,12 \pm 4,99 \mathrm{bc}$ & $2,1 \pm 3,94$ abc & $0 \mathrm{bc}$ & $0 \mathrm{c}$ & $0 \mathrm{~b}$ & $0 \mathrm{~d}$ & $0 \mathrm{c}$ \\
\hline & $11,7 \pm 3,65 \mathrm{abc}$ & $0 \mathrm{c}$ & $0 \mathrm{c}$ & $0 \mathrm{c}$ & $0 \mathrm{c}$ & $0 \mathrm{~b}$ & $0 \mathrm{~d}$ & $0 \mathrm{c}$ \\
\hline & $7,2 \pm 3,65 \mathrm{bc}$ & $6,0 \pm 6,59 \mathrm{abc}$ & $4,0 \pm 6,02 \mathrm{abc}$ & $1,75 \pm 4,94 a b c$ & $2,5 \pm 7,07 \mathrm{c}$ & $2,7 \pm 7,77 \mathrm{~b}$ & $2,7 \pm 7,77 \mathrm{~d}$ & $2,7 \pm 7,77 \mathrm{c}$ \\
\hline & $6,0 \pm 4,24 \mathrm{c}$ & $1,0 \pm 0,35 \mathrm{c}$ & $0 \mathrm{c}$ & $0 \mathrm{c}$ & $0 \mathrm{c}$ & $0 \mathrm{~b}$ & $0 \mathrm{~d}$ & $0 \mathrm{c}$ \\
\hline & $17,6 \pm 8,95$ a & $34,6 \pm 8,84$ a & $44,8 \pm 16,26 \mathrm{a}$ & $41,4 \pm 23,42 \mathrm{a}$ & $26,6 \pm 35,11$ a & $30,4 \pm 48,69$ a & $52,4 \pm 95,34 \mathrm{a}$ & a $70,4 \pm 156,30$ a \\
\hline & $9,1 \pm 1,88$ abc & $18,7 \pm 5,09 \mathrm{ab}$ & $20,7 \pm 16,98 \mathrm{abc}$ & $6,1 \pm 6,46 \mathrm{abc}$ & $1,5 \pm 4,24 \mathrm{c}$ & $1,0 \pm 2,82 \mathrm{~b}$ & $2,2 \pm 6,36 \mathrm{~d}$ & $2,2 \pm 6,36 \mathrm{c}$ \\
\hline & \multicolumn{2}{|c|}{ Produção de pontos verdes } & \multicolumn{3}{|c|}{$\begin{array}{l}\text { Número de plântulas que resistiram ao } \\
\text { transplante para caixa magenta }\end{array}$} & \multicolumn{3}{|c|}{$\begin{array}{l}\text { Número de plantas em vermiculita que } \\
\text { resis tiram ao processo de aclimatização }\end{array}$} \\
\hline LD82025 & \multicolumn{2}{|c|}{$17,34 \pm 11,01 \mathrm{a}$} & \multicolumn{3}{|c|}{$8,0 \pm 6,0 \mathrm{a}$} & \multicolumn{3}{|c|}{$4,34 \pm 4,50 \mathrm{a}$} \\
\hline CD308 & \multicolumn{2}{|c|}{$9,34 \pm 2,51 \mathrm{a}$} & \multicolumn{3}{|c|}{$1,3 \pm 1,52 \mathrm{~b}$} & \multicolumn{3}{|c|}{$0,34 \pm 0,57 \mathrm{~b}$} \\
\hline CML314 & \multicolumn{2}{|c|}{$5,34 \pm 2,31 \mathrm{~b}$} & \multicolumn{3}{|c|}{$0,3 \pm 0,57 \mathrm{~b}$} & \multicolumn{3}{|c|}{$0,34 \pm 0,57 \mathrm{~b}$} \\
\hline
\end{tabular}

Médias não seguidas da mesma letra na coluna, a 10\% de probabilidade de erro, diferem entre si pelo teste de comparações múltiplas no campo nãoparamétrico após o teste de Kruskal-Wallis.

*Friável e embriogênico.

Ciência Rural, v.38, n.9, dez, 2008. 
grande de genótipos que apresentem boas respostas regenerativas proporcionaria oportunidade maior para escolha do genótipo mais responsivo a tal característica. Houve diferença entre os genótipos avaliados quanto à capacidade de embriogênese somática e à regeneração de plantas in vitro a partir de embriões imaturos de milho. Essa diferença indica que o genótipo está relacionado com o sucesso de indução de calos embriogênicos e de regeneração. Para a indução de calo embriogênico e regeneração, a linhagem LD82025 foi a mais promissora para utilização em programas envolvendo transformação genética de plantas.

\section{REFERÊNCIAS}

BRASILEIRO, A.C.M.; CARNEIRO, V.T.C. Manual de transformação genética de plantas. Brasília: SPI/EmbrapaCenargen, 1998. 309p.

CARNEIRO, A.A. et al. Milho transgênico - Melhoria da qualidade nutricional do grão. Revista Biotecnologia Ciência \& Desenvolvimento, Brasília, v.15, p.42-46, 2000. Capturado em 24 abr. 2005. Online. Disponível na Internet: http:// www.biotecnologia.com.br.

CHU, C.C. et al. Establishment of an efficient medium for anther culture of rice through comparative experiments on the nitrogen sources. Science Sinica, Beijing, v.18, p.659-668, 1975.

CONAB, 2005. Safras - Grãos. Capturado em 3 ago. 2005. Online. Disponível na Internet: http://www.conab.gov.br.

DRONNE, S. et al. Desiccation decreases abscisic acid content in hybrid larch (Larix x leptoeuropaea) somatic embryos. Physiology Plantarum, Copenhagen, v.99, n.3, p.433-438, 1997.
GREEN, C.E.; PHILLIPS, R.L. Plant regeneration from tissue cultures of maize. Crop Science, Madison, v.15, p.417-421, 1975.

LEE, E.K. et al. Enhanced production and germination of somatic embryos by temporary starvation in tissue culture of Daucus carota. Plant Cell Reports, New York, v.20, p.408415, 2001.

MACHII, H. et al. Screening wheat genotypes for high callus induction and regeneration capability from and immature embryo cultures. Plant Cell, Tissue and Organ Culture. Dordrecht, v.53, n.1, p.67-74, 1998.

MILACH, S. et al. Regeneração de plantas no cultivo de calos de genótipos brasileiros de trigo. Pesquisa Agropecuária Brasileira, Brasília, v.26, n.11, p.1947-1956, 1991.

OZGEM, M. et al. Callus induction and plant regeneration from immature and mature embryos of winter durum wheat genotypes. Plant Breeding, Madison, v.115, n.6, p.455458, 1996.

SANTOS-SEREJO, J.A.; AGUIAR-PERECIN, M.L.R. Genótipos de milho com alta capacidade para embriogênese somática e regeneração de plantas obtidos a partir de calos. Scientia Agricola, Piracicaba, v.57, p.717-722, 2000.

SMITH, S.M.; STREET, H.E. The decline of embryogenic potential as callus and suspension cultures of carrot (Daucus carota L.) are serially subcultured. Annals of Botany, London, v.38, n.2, p.223-241, 1974.

TOMES, D.T.; SMITH, O.S. The effect of parental genotype or initiation of embryogenic callus from elite maize germplasm. Theoretical Applied Genetics, Heidelberg, v.70, n.5, p.505509, 1985 